\title{
Specialists' training by integration of the high school and business structures
}

\author{
Aleksandra Kobicheva ${ }^{1, *}$, and Anna Safonova ${ }^{1}$ \\ ${ }^{1}$ Peter the Great St. Petersburg Polytechnic University, 195251, St. Petersburg, Russia
}

\begin{abstract}
According to global trends, universities should now be responsible for training a new generation of researchers and highly qualified managers who are ready to implement innovative activities in the modern market economy. This article focuses on the problems of professionalization and training of a modern specialist through the integration of educational and business structures. The purpose of this study is to substantiate the importance of the interaction of universities with business structures as a factor contributing to the solution of these problems and improving the quality of higher education in general. The article provides examples of the interaction of the Higher School of Media Communications and Public Relations (SPbPU) with enterprises based on the implementation of project activities. We have analysed students 'essays regarding participation in this kind of project activity, reflecting positive and negative experiences and allowing us to assess the impact of project activity on students' professional skills. More than $71 \%$ of students noted the significant contribution of project activity to their creativity and professional skills, and thus confirmed the importance of the interaction of higher education with the business environment, primarily for the educational process.
\end{abstract}

\section{Introduction}

In modern economic conditions there are new features of the training of specialized personnel for high-tech enterprises, which make significant changes in the nature of universities $[1,2]$. One of the main tasks of universities today is to update the content, teaching methods, to achieve a new quality of education and learning outcomes [3]. In particular, at present, it is not mass, but individual targeted training of specialists for specific departments of specific enterprises and scientific organizations that is required [4]. At the same time, the task of reducing the time for adaptation of young specialists to the conditions of a particular organization is solved, which is facilitated by the early system of professionalization at the university, namely the system of practices and internships, the application of contract training, employment and retention of specialists.

The purpose of this study is to analyse the influence of project activities of Peter the Great St. Petersburg Polytechnic University on students' professional skills development.

\footnotetext{
* Corresponding author: kobicheva92@gmail.com
} 


\subsection{Literature review}

Researchers Vishnevsky Yu. R., Narkhov D. Yu., Didkovskaya Ya. V. during a long-term monitoring note that the number of students planning to work in their specialty, almost doubled from 1995 to 2016 - from $66 \%$ to $34 \%$ [5].

As the reasons for deprofessionalization, the authors call the weakening of the career guidance system, the emergence of a "postponed choice" situation, when school graduates are not ready for a responsible decision about their professional education; socio-economic trends, including individualization; changes in the need-motivational sphere of modern youth, its value orientations and attitudes, etc.

The relevance of the problems of professionalization and training of a modern specialist determines not only a radical change in the educational process itself, but also requires increased interaction between the university and enterprises, both in the educational process and in solving production and scientific problems, attracting significant additional funds for the organization of the educational process [6].

Today, the professionalization of youth largely determines the competitiveness of the national labor market, forming additional competitive advantages, accumulating development potential and preventing crises in the modern complex sphere of labor relations [7]. Despite the fact that professionalization as a process lasts throughout life, the "student stage" is especially important, during which the young person achieves selfactualization, forms professional self-awareness, motivation to master the profession [8].

Problems of the educational process, scientific research and business integration, and as a result training of a new generation of researchers and highly qualified managers are considered in the many works by Russian researchers $[9,10]$.

Starting from the end of the 20th century the general trend of the science-intensive education growth and the growth of intelligence and educational intensity of the economies of developed countries requires Russia, which meets global trends, to train a new generation of researchers and highly qualified managers who are ready to implement innovative activities in modern market economies [11].

Igolkin S. L. and Smolyaninova I. V. distinguish the following advantages of integration development along the path "education-science-business":

- for students, this is an extension of experience and an increase in the quality of education, as well as an expansion of opportunities for further employment;

- for the university - enhancing scientific reputation, achieving a mission in the field of education, research and innovation;

- for business - access to the latest research and innovation, the ability to reduce costs and risks in the implementation of their activities;

- for society - increasing the level of employment, supporting industry and developing the level of production in the region, etc. [12].

To fulfill these strategic tasks of joint interaction, it is necessary to concentrate the resources of interested enterprises, research institutions and universities. It should also be understood that the initiative for integration processes should come, on the one hand, from higher education institutions as the central agent of the national innovation system, and on the other hand, from business enterprises, as a party interested in new scientific developments and training competent personnel for work in business enterprises [13, 14].

\section{Methodology}

To implement our study we analysed the essays on the training of 106 students who participated in 38 projects from 2017 to 2019. All essays were divided into 3 types: positive, neutral and negative, so it gave us an opportunity to make qualitative assessment 
of project activities' influence on students' professional skills development and their satisfaction with those projects at all.

Implementing the study we answered the following research questions:

1. Does project activities significantly improve the professional skills of students?

2.How students perceive the experience of project training?

\section{Results and Discussion}

\subsection{Project activities of SPbPU}

The Higher School of Media Communications and Public Relations, which is part of the humanitarian institute of Peter the Great St. Petersburg Polytechnic University, is interested in long-term cooperation with companies and agencies operating in the market of St. Petersburg. Partnerships are secured by cooperation agreements, allowing to balance the interests of partner organizations and student interns.

This cooperation includes:

1. Creating a pool of practitioners to engage in training sessions.

2. Organization of the student section as part of the SPbPU Science Week Science Forum with a competition for the best solution of cases from practitioners.

3. The direction of students of the department for educational, industrial and undergraduate practice in industry organizations.

4. Creation of a Center for Sociological Research on the basis of a higher school.

5. The entry of higher education into professional associations and ensuring the participation of students in professional competitions, forums and conferences.

Particular importance is given to the real projects implementation by students in the field of advertising, marketing and PR at the request of companies as part of a dispersed project practice.

Project activities at the Higher School of Media Communications and Public Relations are carried out in the process of preparing bachelors (in the third year of study) and masters (in the first and second years of study) as part of a dispersed practice with the aim of creating a portfolio of individual achievements of project participants and integrating future specialists into business Wednesday

The Higher School has developed and approved the regulation of project activities (dispersed project practice), which allows to control the process of organizing and managing projects.

Third year bachelor, as well as first and second years master students are given the opportunity and variability of the choice of projects from external (company, agency, etc.) and internal (structural units of the university) customers. The student's integration process into professional project activities allows them to acquire skills in multi-channel attention mode, learn to maintain efficiency while working in several areas at the same time, develop a high-quality project plan and assess risks, attract resources and organize communication, monitor the progress of work and distribute current tasks.

Dispersed project practice consists of four successive stages: initiation, planning, implementation and completion.

At the initiation stage, the methodology of searching for external customers from among the commercial organizations of St. Petersburg is implemented and a communication model of interaction with the customer is developed, depending on the specifics of the project and the direction of the customer's company.

At the planning stage, an application for the project is formed together with the customer, primary information about the project is specified, functional roles are 
determined, scheduling is carried out, possible risks are predicted and expected results are formulated. The planning stage ends with the announcement and presentation of the project in the group of higher school Vkontakte "Project Activities" [15], the formation of the project team with the appointment of the project manager from among the students and the preparation of related documentation.

It is important to note that when recruiting students for a project, the rules of variability, freedom of choice, change of roles and self-determination are implemented. Thus, students independently choose in which project, in which role and in the composition of which working group to participate. These rules take into account students' expectations both in terms of obtaining a specific result (product, effect) from the project, and in terms of their acquisition of group interaction skills.

In order to monitor the implementation of the project, a number of guidelines for project management, on-going monitoring of project implementation and analysis of the results have been developed.

Duration of projects varies from 3-4 weeks to 2 months, depending on the complexity of the task. The terms are approved by the customer companies, the training hourly load is determined by the work curriculum.

The directions of projects most demanded by external customers (business structures) were identified and systematized, which include:

- PR and advertising promotion of a product / product / service;

- marketing in social networks (social media marketing);

- organization and holding of special events and events;

- organization and conduct of sociological research;

- shooting video clips (video production).

For each type of project, instructions on the rules for the design of the reporting presentation were developed for students in order to effectively present the results.

At the stage of completion of the project, a working group of students prepares a report for the customer, after which it receives a written review of participation in the project.

A special format for project reporting documents aimed at developing a participant's ability to analyse their own experience in participating in a specific project is a reflective essay. In the process of compiling an essay, the student must answer questions about the personal purpose of participating in the project, about what he managed to and failed to do, what difficulties he had to face, and also what new knowledge, abilities and skills he acquired.

An essay, a written review of the customer, an individual practice plan and report are submitted for verification to the managers of the project practice, after which the working group of the project is allowed to public defense in front of the academic staff of the Higher School and representatives of the customer company.

During 2017-2018 students implemented the projects of the following companies: "St Friday Socks", "White label", "RIA Fartuna", marketing agency "EU", event-agency "Geekers". During this process students were able to participate in the development of product concepts, promotion media content of companies, brand identity development and positioning. Students analysed competitors' goods and services, studied consumer behaviour, developed and filled out advertising materials, prepared press releases, organized interviews, created videos and evaluated the effectiveness of the work done.

Based on the recommendations received from partner companies, new promising professional competencies were identified that formed the basis for the development of an educational standard independently established by the educational organization (EMS) and were included in the competency matrix. Practical courses such as Sociological Media Measurement, Planning and Organization of Congress and Exhibition Activities, Network Communications and Converged Media, etc. were introduced into the curriculum. 


\subsection{Reflective essay analysis}

The results of the analysis showed the following: 5 people $(4.7 \%)$ described the experience of project practice as "negative" and noted the following: "there was not enough available knowledge and skills", "it was not possible to obtain new knowledge", and "the project was too long and uninteresting". In an essays that were neutral in nature - 25 students $(23.6 \%)$ noted: "difficulties and inconsistencies in the organization of the work process", "this type of practice was useful, but did not bring new knowledge and professional experience", or the input of practice students understood that "they would like to try themselves in a different role." Positive essays were submitted by 76 students (71.7\%). These essays were stained with such marker phrases as: "solving new problems", "valuable experience", "huge amount of positive emotions", "I was able to realize my creative potential", "I learned much more than in the process of past practices ", Successfully worked as a team "," personal victory", etc.

Also, in the course of the analysis, 4 qualitative categories were distinguished, which can be divided into 2 groups: positive and negative experience of student learning. The results are presented in Table 1.

Table 1. Descriptive results of intercultural communication attributes.

\begin{tabular}{|c|c|c|c|}
\hline \multicolumn{2}{|c|}{ Positive experience } & \multicolumn{2}{|c|}{ Negative experience } \\
\hline Category & Sub-category & Category & Sub-category \\
\hline $\begin{array}{l}\text { Student Competency } \\
\text { Development }\end{array}$ & $\begin{array}{l}\text { - Teamwork } \\
\text { - Leadership } \\
\text { - Communication } \\
\text { skills } \\
\text { - Solution of problems } \\
\text { - Time management }\end{array}$ & Lack of competencies & $\begin{array}{l}\text { - Lack of professional } \\
\text { knowledge } \\
\text { - Low development of } \\
\text { problem-solving } \\
\text { competency }\end{array}$ \\
\hline Project organization & $\begin{array}{l}\text { - High student } \\
\text { engagement } \\
\text { - Increased learning } \\
\text { motivation } \\
\text { - Interest in solving } \\
\text { real problems and } \\
\text { achieving results }\end{array}$ & Project consistency & $\begin{array}{l}\text { - Unclearly defined } \\
\text { goals and objectives of } \\
\text { the project } \\
\text { - Difficulties in } \\
\text { communicating with } \\
\text { project customers } \\
\text { when questions arise }\end{array}$ \\
\hline
\end{tabular}

It should be noted that an important condition for submitting an essay is compliance with the deadlines, namely, no later than 3 days ( 72 hours) from the completion of the project. This rule is designed to provide the most reliable reflective introspection of personal participation in the project, so results of essays can be considered as reliable.

\section{Conclusion}

It can be clearly said that after students undergo project-based dispersed practice, the theoretical principles learned during lectures and seminars, as well as in the process of independent work, are tested in practical studies at enterprises, in advertising, communication and marketing agencies and are reinforced by personal experience of students, allow to create the required professional skills and simulate the situation of work in the chosen specialty. A high-quality approach to the selection of projects determines the competitiveness of a future specialist in the labor market.

Thus, the Higher School of Media Communications and Public Relations makes a significant contribution to the development of higher education and gives the graduates of the department human capital that can create high added value in the workplace in the future. 


\section{References}

1. V.V. Glukhov, N.O. Vasetskaya, Proceedings of the 2017 IEEE VI Forum Strategic Partnership of Universities and Enterprises of Hi-Tech Branches (Science. Education. Innovations) (SPUE), 17-21 (2017).

2. S. Barykin, A. Kobicheva, MATEC Web of Conferences 170, 01020 (2018). doi:10.1051/matecconf/201817001020

3. T.A. Baranova, A.M. Kobicheva, E.Y. Tokareva, ACM International Conference Proceeding Series, 140-145 (2019). doi:10.1145/3323771.3323779

4. T. Baranova, A. Kobicheva, E. Tokareva, Advances in Intelligent Systems and Computing 1114, (2020).

5. Yu. R. Vishnevsky, D. Yu. Narkhov, Ya. V. Didkovskaya, Education and science 1, 152-168 (2018).

6. L. Pushkareva, M. Pushkarev. E3S Web of Conferences 135, 04070 (2019). doi:10.1051/e3sconf/201913504070

7. V.N. Snetkov, A.V. Ponomarenko, K.A. Semenova, J.IOP Conf. Series: Earth Environ. Sci. 32, 012030 (2019). doi:10.1088/1755-1315/302/1/012030

8. E. G. Pozdeeva, O. D. Shipunova, L. I. Evseeva, IOP Conference Series: Earth and Environmental Science 337, 012049 (2019). doi:10.1088/1755-1315/337/1/012049

9. S. M. Markova, Socialization and professionalization of personality as the goal of vocational education. Theory and practice of social development 12 (2013).

10. O.D. Shipunova, I.P. Berezovskaya, L.V. Mureiko, V.V. Evseev, L.I. Evseeva, Revista ESPACIOS 39(40), 15 (2018).

11. E. Krzaklewska, S. Krupnik, Exchange Students' Rights, Erasmus Student Network: Brussels (2007).

12. S. L. Igolkin, I. V. Smolyaninova, Materials of the I international scientific-practical conference, 410-413 (2015).

13. N. M. Zinovieva, Territory of science 6 (2015).

14. L.I. Evseeva, O.D. Shipunova, E.G. Pozdeeva, I.R. Trostinskaya, V.V. Evseev, The 2018 International Conference on Digital Science, 241-251 (Springer, Cham, 2020) doi:10.1007/978-3-030-37737-3_22

15. https://vk.com/project_rso 